(C) Group of authors, 2016

UDC 618.14-002:577.15+546.46

DOI - http://dx.doi.org/10.14300/mnnc.2016.11040

ISSN - 2073-8137

\title{
ROLE OF GELATINASE B AND INTRAERYTHROCYTIC MAGNESIUM IN FORMATION OF THE CHRONIC ENDOMETRIUM INFLAMMATION IN RATS
}

\author{
Rogova L. N., Tikhaeva K. Yu., Tkachenko L. V. \\ Volgograd State Medical University, Russian Federation \\ РОАЬ ЖЕААТИНАЗЫ В И ВНУТРИЭРИТРОЦИТАРНОГО МАГНИЯ
В МЕХАНИЗМАХ ХРОНИЗАЦИИ ВОСПААЕНИЯ ЭНАОМЕТРИЯ У КРЫС
}

\author{
А. Н. Рогова, К. Ю. Тихаева, А. В. Ткаченко
}

ВолгограАский госуАарственный меАицинский университет, Российская ФеАерация

In the study was evaluated the role of intraerythrocytic magnesium, the specific number and intensity of expression of gelatinase B positive cells on the mechanisms of chronic experimental inflammation of the endometrium in rats. Experiment was performed on 40 adult female white Wistar rats, which were divided into 3 groups. The first group $(n=10)$ - initial state, the second group $(n=10)$ - control series, the third group $(n=10)$ - simulation of endometritis. On the 51st day after modeling chronic inflammation of the endometrium of the rats were receiving the blood from the inferior Vena cava and subclavian veins, the tissue of the uterine wall. Our study showed a reduction in the specific number of gelatinase B positive cells in the stroma (cellular component), the intensity of expression decreased of gelatinase-B in both the stroma and glandular epithelium. The decrease in intraerythrocytic levels of magnesium in the blood from different regions is a strong direct correlation with the number and intensity of expression gelatinase $B$. Thus, the decrease of intraerythrocytic magnesium, immunohistochemically activity indicators of gelatinase $B$ on the background of the morphological picture of chronic endometritis, act as important links of the chronic endometrium inflammation.

Key words: chronic endometritis, gelatinase, magnesium

В исследовании проведена оценка роли внутриэритроцитарного магния, удельного числа и интенсивности экспрессии желатиназа-В позитивных клеток в механизмах хронизации экспериментального воспаления эндометрия у крыс. Эксперимент был выполнен на 40 половозрелых самках белых крыс линии Вистар, которые были поделены на 3 группы. Первая группа $(n=10)$ - исходное состояние, вторая группа $(n=10)-$ контрольная серия, третья группа ( $n=10)$ - моделирование эндометрита. На 51-е сутки с момента моделирования хронического воспаления эндометрия у крыс получали кровь из нижней полой и подключичной вен и ткань стенки матки. Проведенное исследование показало уменьшение удельного числа желатиназа-В позитивных клеток в строме (клеточном компоненте). Интенсивность экспрессии желатиназы В снижалась как в строме, так и в железистом эпителии. Уменьшение уровня внутриэритроцитарного магния в крови из разных регионов находилось в прямой корреляционной зависимости с числом и интенсивностью экспрессии желатиназы В. Таким образом, снижение внутриэритроцитарного магния, иммуногистохимических показателей активности желатиназы В на фоне морфологической картины хронического эндометрита выступает как значимые звенья хронизации воспаления эндометрия.

Ключевые слова: хронический эндометрит, желатиназа $B$, магний

A ccording to modern data, chronic endometritis is the result of imbalance between hormonal and immune systems of the body, on the one hand, and microbial pathogens on the other. The disease can develop as an outcome of inadequate treatment of acute endometritis, and as primary chronization, in women with abnormal balance between the activity of the processes of destruction, remodeling and proliferation of tissues (primary genetic defects, immunodeficiency, etc.) [8].

Remodeling of the extracellular matrix one of the main mechanisms for maintaining the homeostasis in any tissue, as in norm and in pathology. The activity of matrix metalloproteinases is an important factor determining the intensity of remodeling of the extracellular matrix [4, $5]$. There is evidence of gelatinase $B$ role in metastasis in oncology, in the formation and development of arthritis, paradontitis, ulcer defects of gastro-intestinal tract. Note, that performance of the activity of metalloproteinases (gelatinase, collagenases, stromelysin, etc.) changes in different ways, reflecting, in some cases, destructive processes, and initiation of cell proliferation in others $[6,7]$. Nowdays we have no unambiguous information about the role and importance of metalloproteinases in the pathogenesis of acute and chronic inflammation, including the pathogenesis of chronic endometritis. Insufficiently stu- 
died the problem of these enzymes e activity correcting. The literature contains data on the role of cytokines, free radicals in regulating the activity of metalloproteinases. A separate work on the role of magnesium in the modulation of gelatinase $B$ activity $[1,10,11]$.

The aim of the study was to evaluate the role of intraerythrocytic magnesium, the specific number and intensity of expression of gelatinase - B positive cells in the mechanisms of chronization of experimental inflammation of the endometrium in rats.

Material and Methods. The experiment was performed on 40 adult female white Wistar rats weighing $198 \pm 3.8 \mathrm{~g}$. Experimental animals of experimental and control groups were kept in standard conditions in compliance with the Declaration of Helsinki of the world medical Association (1964), ethical principles of the European science Foundation (ESF), the Order of the USSR Ministry of health № 755 from 12.08.77 «About measures on further improvement of forms of work with experimental animals», the rules of work with experimental animals (Shalimov, 1990; Berezovskaya, 1993; Suffin, 1993); Federal law dated 24.04.1995, № 52-FZ «On fauna», the GLP - rules of laboratory practice (order of the Ministry of health of the Russian Federation dated 19.06.2003, № 266).

Before the experiment the animals were divided into 3 groups. In group $1(n=10)$ was determined the studied parameters in the initial state. The second - control series $(n=10)$ performed the same manipulations as in the main (third group), but did not display chronic inflammation of the endometrium. In the third $(n=20)$ simulated chronic inflammation of the endometrium by introduction into the uterus of autoclaves suspension in a volume of $0.1 \mathrm{ml}$ [9]. From the third day after surgery, the animals of the second and third groups underwent antibacterial therapy with broad-spectrum drug Ceftriaxone in accordance with the weight of the animal within 7 days.

51 day withdrawal of animals from the experiment, by injecting lethal doses of Rometar. After having received the blood from the subclavian veins and the lower hollow veins was performed tissue sampling for histological and immunohistochemical studies. The resulting preparation was fixed in neutral buffered formalin and after dehydration in a series of alcohols of increasing concentration were filled with wax by the standard technique. Histological techniques included painting with hematoxylin-eosin. Study the expression of MMP-9, was conducted by immunohistochemical method according to standard methods using antibodies firm «Novocastra» MMP-9 (NCL-MMP9, paraffin blocks, working dilution 1:40), (Kokosadze N. In., Zagodirenko K. V., 2006; Mac C. D. et al., 1993). In preparations at 400 -fold magnification was evaluated as the specific number (\%) of positively stained cells in 5 randomly selected fields of view ( $\geq 500$ cells). The staining reaction was assessed as negative -0 points, mild 1 point, medium (moderate) -2 points expressed 3 points.

The concentration of magnesium in erythrocytes was determined by reaction with titanium yellow. To determine the concentration of magnesium used plasma diagnostic kit of the firm «Lachema» (Czech Republic).

To assess morphological patterns of endometrial tissue was used semi-quantitative method of assessing the severity of lymphocytic, plasmocytes infiltration of endometrial stroma in biopsy material, developed by E. A. Ka- zachkova [2]. For statistical processing o the results of the study used student test (mean values expressed as $\mathrm{M} \pm \mathrm{m}$ ). In the distribution other than normal, used the Wilcoxon test (mean values expressed as IU [ 25 and 75 percentile]) and correlation according to Spearman.

Results and Discussion. Histological examination of endometrial tissue in rats of the first group revealed individual neutrophils, lymphocytes, rounded glands normal structure of arteries without features. In the second (control) group, follow the morphological pattern was almost identical to the indicators in the initial state. At the same time, as can be seen from Table 1, statistically significant differences in the parameters of cellular infiltration of the endometrium between the first and second groups were: the number of neutrophils, macrophages, lymphocytes, plasma cells and eosinophils in the initial state: $1[0 ; 1] 1 ; 1[0 ; 1] ; 1[1 ; 1] ; 1[0 ; 1]$; $0[0 ; 0] ; 1[1 ; 2]$ points to be controlled: $1[1 ; 2],(Q>0.1)$; $1[0 ; 1],(\mathrm{Q}>0.1) ; 1[0.25 ; 1],(\mathrm{Q}>0.1) ; 0[0 ; 0],(\mathrm{Q}>0.1)$; $1[1 ; 0],(Q>0.1)$, respectively.

Table 1

The performance of cellular infiltration in the endometrium (in points) (Me [25 and 75 percentiles])

\begin{tabular}{|l|c|c|c|c|c|}
\hline & $\begin{array}{c}\text { neu- } \\
\text { tro- } \\
\text { phil }\end{array}$ & $\begin{array}{c}\text { macro- } \\
\text { phage }\end{array}$ & $\begin{array}{c}\text { lympho- } \\
\text { cyte }\end{array}$ & $\begin{array}{c}\text { plas- } \\
\text { mo- } \\
\text { cyte }\end{array}$ & $\begin{array}{c}\text { eosino- } \\
\text { phyl }\end{array}$ \\
\hline Group 1 & $1[0 ; 1]$ & $1[0 ; 1]$ & $1[1 ; 1]$ & $0[0 ; 0]$ & $1[1 ; 2]$ \\
\hline Group 2 & $1[1 ; 2]$ & $1[0 ; 1]$ & $1[0.25 ; 1]$ & $0[0 ; 0]$ & $1[1 ; 0]$ \\
\hline Group 3 & $1[0 ; 1]$ & $\begin{array}{c}1.5 \\
{[1.5 ; 2]}\end{array}$ & $2.5[1.5 ; 3]$ & $2[1 ; 3]$ & $1.5[1.5 ; 2]$ \\
\hline $\mathrm{Q}$ & $>0.1$ & $>0.1$ & $>0.1$ & $>0.1$ & $>0.1$ \\
\hline $\mathrm{Q}^{1}$ & $>0.1$ & $<0.05$ & $<0.01$ & $<0.001$ & $<0.01$ \\
\hline
\end{tabular}

$\mathrm{Q}$ - the reliability of differences between the initial state and control;

$Q^{1}$ - reliability of differences between the group with experimental chronic inflammation of the endometrium and control.

In the third group in the histological material were found: inflammatory infiltrates of lymphoid cells, to a lesser degree from the leucocytes, often located around glands and blood vessels, rarely diffuse, plasmatic cells, single macrophages, mild stromal fibrosis, slight sclerosis of the walls of arteries of the endometrium. In animals of the third group significantly increased level of macrophages $1.5[1.5 ; 2],(Q<0.05)$, lymphocytes of 2.5 $[1.5 ; 3],(Q<0.01)$, and plasmocytes $2[1 ; 3],(Q<0.001)$, eosinophilia 1.5 [1.5; 2], $(\mathrm{Q}<0.01)$.

As is known, the morphological criteria of chronic endometritis are lymphocytes and plasmocytes infiltrates, detection of focuses of fibrosis in the stroma and in the walls of the spiral arteries, predominantly in the basal layer of the endometrium [3].

Analysis of the results shows that in the tissues of the uterus, the endometrium, formed morphological signs of chronic inflammation. Simultaneously with the change of parameters of cellular infiltration changed the specific number and intensity of expression of gelatinase - B positive cells in the tissues of the endometrium in the study groups (Table 2). At 51 days after modeling in experimental animals revealed a reduction of the specific number and intensity of expression of gelatinase-B positive cells in the stroma elements $(Q<0.05)$ on the background of practically unchanged specific numbers in the glandular epithelium $(\mathrm{Q}>0.1)$. 
Specific number and intensity of expression of gelatinase B-positive cells in the tissues of the endometrium on the background of experimental chronic inflammation of the endometrium (in points) (IU [25 and 75 percentiles])

\begin{tabular}{|c|c|c|c|c|c|c|}
\hline \multicolumn{2}{|c|}{ Indicators } & $\begin{array}{c}\text { Group } \\
1\end{array}$ & $\begin{array}{c}\text { Group } \\
2\end{array}$ & Group 3 & $\mathrm{Q}$ & $\mathrm{Q}^{1}$ \\
\hline \multirow{2}{*}{$\begin{array}{l}\text { Stro- } \\
\text { ma } \\
\text { (cel- } \\
\text { lular } \\
\text { com- } \\
\text { po- } \\
\text { nent) }\end{array}$} & $\begin{array}{l}\text { Specific } \\
\text { number } \\
\text { (в \%) }\end{array}$ & $\begin{array}{c}28 \\
{[26 ; 30]}\end{array}$ & $\begin{array}{c}28 \\
{[20 ; 30]}\end{array}$ & $\begin{array}{c}18 \\
{[17 ; 20]}\end{array}$ & $>0.1$ & $<0.05$ \\
\hline & $\begin{array}{l}\text { Inten- } \\
\text { sity of } \\
\text { expres- } \\
\text { sion (in } \\
\text { points) }\end{array}$ & $2[0 ; 1]$ & $2[0 ; 2]$ & $0[1 ; 2]$ & $>0.1$ & $<0.05$ \\
\hline \multirow{2}{*}{$\begin{array}{l}\text { Glan- } \\
\text { dular } \\
\text { epi- } \\
\text { theli- } \\
\text { um }\end{array}$} & $\begin{array}{l}\text { Specific } \\
\text { number } \\
(\text { в \%) }\end{array}$ & $\begin{array}{c}29 \\
{[28 ; 30]}\end{array}$ & $\begin{array}{c}30 \\
{[28 ; 30]}\end{array}$ & $\begin{array}{c}26.5 \\
{[22 ; 25]}\end{array}$ & $>0.1$ & $>0.1$ \\
\hline & $\begin{array}{l}\text { Inten- } \\
\text { sity of } \\
\text { expres- } \\
\text { sion (in } \\
\text { points) }\end{array}$ & $2[0 ; 1]$ & $2[0 ; 1]$ & $1[1 ; 2]$ & $>0.1$ & $<0.05$ \\
\hline
\end{tabular}

$\mathrm{Q}$ - the significance of differences between baseline and follow-up;

$\mathrm{Q}^{1-}$ the significance of differences between the group with experimental chronic inflammation of the endometrium and control.

The reduction of the specific number of gelatinase-B positive cells in the stroma while reducing the intensity of their expression in the stromal component and in glandular epithelium in the presence of morphological signs of inflammation indicate a continued destruction of tissue and signs of chronic inflammation.

It is known that one of the important conditions of increased proliferation in the area of inflammation is destruction of the damaged tissue and elimination of flogogen. In these processes an important role plays enzymes of the lysosomes, hydrolases and, of course, metalloproteinases. In the literature there are single information in which data indicating that the optimum magnesium content in the tissue, on the one hand, strengthens energyproduction, required to enhance proliferation, on the other hand, may be one of the mechanisms regulating the activity of metalloproteinases. To determine the role of magnesium in regulating the

References

1. Gromova O. A. Magnesium and pyridoxine: basic knowledge Prototype. 2006. 234 p.

2. Poteryaeva O. N., Antonov A. R., Kim N. A., Nekrasova M. F. Fundamental and applied problems of medicine and biologii. 2006. $40 \mathrm{p}$.

3. Rogova L. N. Matrix metalloproteinases, and their role in physiological and pathological processes (review). Vestn. new medic. technologies. 2011;8(2):86-89.

4. Rogova L. N., Shesternina N. V., Starovoytov V. A. Effect of magnesium composition on magnesium balance, intensity of peroxidation and activity of antioxidant enzymes in rats with gastric ulcer acetate. Vestn. new medic. technologies. 2011;8(2):89-91.

5. Solovyova N. I. Bioorganic Chemistry. 1998;24(4):245255.

6. Sukhih G. T., Shurshalina A. V. Chronic endometritis: manual. M: «GEOTAR Media»; 2010. 64 p. activity of gelatinase $B$ in the tissues of the endometrium was determined by its intraerythrocytic levels in the blood of the subclavian veins and inferior Vena (Table 3).

Table 3

The content of magnesium in erythrocytic mass in rats on the background of chronic inflammation of the endometrium

\begin{tabular}{|l|c|c|c|c|c|}
\hline $\mathrm{Mg}^{2+} \mathrm{mmol} / \mathrm{l}$ & Group1 & Group 2 & $\mathrm{P}$ & Group 3 & $\mathrm{P}^{1}$ \\
\hline $\begin{array}{l}\text { Lower } \\
\text { hollow } \\
\text { vein } \\
\text { (er.mass) }\end{array}$ & $1.91 \pm 0.07$ & $1.871 \pm 0.09$ & $>0.1$ & $1.63 \pm 0.06$ & $<0.01$ \\
\hline $\begin{array}{l}\text { Subclavian } \\
\text { vein } \\
\text { (er.mass) }\end{array}$ & $1.78 \pm 0.12$ & $1.73 \pm 0.12$ & $>0.1$ & $1.49 \pm 0.06$ & $<0.05$ \\
\hline
\end{tabular}

$P$ - significance of differences between baseline and follow-up;

$\mathrm{P}^{1}-$ significance of differences between the group with experimental chronic inflammation of the endometrium and control.

On the background of experimental chronic inflammation of the endometrium in red cell mass in the blood from the inferior Vena cava and subclavian veins had a marked decrease of magnesium from $1.871 \pm 0.09$ to $1.63 \pm 0.19 \mathrm{mmol} / \mathrm{l}(\mathrm{p}<0.01)$, from $1.73 \pm 0.12$ to $1.49 \pm 0.18$ $\mathrm{mmol} / \mathrm{l}(\mathrm{p}<0.05)$ by $18 \%$ and $14 \%$ respectively.

When conducting the correlation analysis revealed a strong direct relationship between levels of intracellular magnesium in the blood from the lower hollow and subclavian veins and a specific number of gelatinase $B$ positive cells in the tissues of the endometrium $r=0.71$; $r=0.7$

The role of magnesium in stabilizing mRNA and noncoding as an activator of enzymes of energy production and consumption is well known. The decrease in the level of magnesium in red blood cell pool does not create conditions for reparation of defects, decreases gelatinase $B$ activity, and leads to accumulation of products of incomplete degradation of the matrix in tissues, which is one of mechanisms of the chronization inflammation.

Conclusions. Our study showed that decreasing the number and intensity of expression of gelatinase - B positive cells in the structures of the endometrium on the background of the development of hypomagnesaemia act as the factors of endometrium experimental inflammation chronization

7. Tikhaeva K. L., Tkachenko L. V., Rogova L. N., Kurkin D. V. The modeling method of chronic endometrium inflammation and its pathogenetic substantiation Volgograd. Journal of Medical Science. 2015;45(1):3134.

8. Egeblad M., Werb Z. New functions for the matrix metalloproteinases in cancer progression. Nat. Rev. Cancer. 2002;2(3):161-174.

9. Rubin $H$. The logic of Membrane, Magnesium, Mitosis (MMM) model for the regulation of animal cell proliferation. Science. 2003;261:1280-1281.

10. Baker A. B. Metalloproteinase inhibitors: biological actions and therapeutic opportunities. J. Cell. Science. 2002;115:3719-3727

11. Inagaki N. Analysis of intrauterine cytokine concentration and matrix-metalloproteinase activity in women with recurrent failed embryo transfer. Human Reproduction. 2003; 18(3):608-615.

\section{About authors:}

Rogova Lyudmila, MD, PhD, Professor, Head of Department of Pathological Physiology and Clinical Pathophysiology; tel.: +7(8442)990551; e-mail: rogova.In@mail.ru

Tikhaeva Ksenya, assistant of Department of Pathological Physiology and Clinical Pathophysiology; tel.: +7(8442)990551; e-mail: tikhaeva34@gmail.com

Tkachenko Lyudmila, MD, PhD, Professor, Head of Department of Obstetrics and Gynecology; tel.: $+7(8442) 467059$ 